\title{
Design of High Compressive Strength Concrete Mix without Additives
}

\author{
Akasha, N, M. ${ }^{1}$, Mansour Ahmed Mohamed ${ }^{2}$, Nasreen Maruiod Abdelrazig ${ }^{3}$ \\ ${ }^{1,2}$ (Assistant professor, School of civil engineering, College of engineering/ Sudan University of science and \\ technology, Sudan). \\ ${ }^{3}$ (MSc. Candidate, School of civil engineering, College of engineering/Sudan University of science and \\ technology, Sudan).
}

\begin{abstract}
In this paper, the crashed Basalt and uncrushed granite is used in concrete mixes as coarse aggregate. The selected materials, with high specification using special production techniques, the properties ,the mix design procedure and mix proportion of the high strength concrete (HSC) were discussed. Different proportions of Ordinary Portland cement $(410,430$ and 450$) \mathrm{kg} / \mathrm{m}^{3}$ with different crashed Basalt and uncrushed Granite coarse aggregate amount $(1120$ and 1050$) \mathrm{kg} / \mathrm{m}^{3}$ and fine aggregate with fine modulus of 3.65 were used. Eight concrete mixes were prepared: two as control mix for crashed Basalt and uncrushed Granite, three with crashed Basalt and three with uncrushed Granite coarse aggregate with mix amount(410:680:1120,430:610:1050 and 450:550:1050) kg/m3, (cement: fine aggregate: coarse aggregate)respectively. The study showed that the use of granite coarse aggregate in concrete mixes has a clear effect in mix proportion. The compressive strength of concrete was measured at ages of 7, 28 and 56 days and it was found that the granite (Mix3) of (450:550:1050) $\mathrm{kg} / \mathrm{m}^{3}$ with w/c of 0.46 give the highest of strength in 28 and 56 days among the abovementioned mixes its 56 and $64 \mathrm{~N} / \mathrm{mm}^{2}$ respectively. The paper shows that good results of compressive strength and workability of concrete were obtained when using granite coarse aggregate.

Keywords: Concrete, Basalt coarse aggregate, uncrushed Granite coarse aggregate, Compressive strength.
\end{abstract}

\section{INTRODUCTION}

Concrete is one of the most common materials and widely used in construction work it plays an important role in infrastructure and private buildings construction. Understanding the basic behaviours of concrete is essential for civil engineering students to become civil engineering profession Concrete is a manmade building material that looks like stone. The word "concrete" is derived from the Latin concretus, meaning "to grow together." Concrete is a composite material composed of coarse granular material (the aggregate or filler) embedded in a hard matrix of material (the cement or binder) that fills the space among the aggregate particles and glues them together. Alternatively, we can say that concrete is a composite material that consists essentially of a binding medium in which are embedded particles or fragments of aggregates. The simplest definition of concrete can be written as: Concrete: filler + binder .Depending on what kind of binder is used, concrete can be named in different waysals. As a structural material, the compressive strength at an age of 28 days is the main design index for concrete $^{[1,2,3 \text {, and } 4]}$. There are several reasons for choosing compressive strength as the representative index. First, concrete is used in a structure mainly to resist the compression force. Second, the measurement of compressive strength is relatively easier. Finally, it is thought that other properties of concrete can be related to its compressive strength through the microstructure. Pursuing high compressive strength has been an important direction of concrete development. A high compressive strength could be achieved by reducing the w/c ratio. However, to keep a concrete workable, there is a minimum requirement on the amount of water; hence, the w/c ratio reduction is limited, unless other measures are provided to improve concrete's workability ${ }^{[5,6 a n d}{ }^{7]}$. For this reason, progress in achieving high compressive strength High strength concrete is a type of high performance concrete. The primary difference between high strength concrete and normalstrength concrete relates to the compressive strength that refers to the maximum resistance of a concrete sample to be applied pressure although there is no precise point of separation between high strength concrete and normal strength of concrete. The American concrete institute ACI ${ }^{[1]}$ defines high strength concrete as concrete with a compressive strength greater than $41 \mathrm{MPa}$ (6000psi). high strength concrete is a superior product with increased modulus of elasticity, lower creep and drying, Shrinkage, excellent freeze thaw resistance, low permeability and increased chemical resistance high strength concrete is specified where reduced weight is important or 
where architectural considerations call for small support element by carrying load more efficiently than normal strength concrete High strength concrete HSC also reduces the total amount of materials placed and lower the overall cost of the structure, Although a $97 \mathrm{MPa}$ (14000psi) concrete costs approximately three time as much as a 20 MPa (3000 Psi) concrete, its compressive strength is nearly five times greater, thus it is economical $^{[8,9]}$. In this research work the locally available constituents material of concrete were selected for the purpose to obtained high strength concrete HSC.

\section{CASE STUDY}

This paper deals with HSC, special requirements, additional special materials and the benefits of its use in the structural members of buildings. Basic ingredients of HSC are generally the same as normal strength concrete "NSC' (i.e. cement, fine aggregate, coarse aggregate, water). Higher material quality may be needed in HSC. In this paper concrete mixes were designed, prepared and tested in the laboratory. At first tests were carried out on the components of concrete mix (cement, coarse aggregate, fine aggregate and water) then several concrete mixes were prepared

Table 1 Properties of Aggregate

\begin{tabular}{|l|l|l|l|}
\hline \multirow{2}{*}{ Properties } & \multicolumn{2}{|l|}{$\begin{array}{l}\text { Coarse } \\
\text { Aggregate }\end{array}$} & \multirow{2}{*}{$\begin{array}{l}\text { Fine } \\
\text { Aggregate }\end{array}$} \\
\cline { 2 - 3 } & Basalt & Granite & \\
\hline $\begin{array}{l}\text { Specific } \\
\text { gravity }\end{array}$ & 2.855 & 2.54 & 2.59 \\
\hline Apparent & 2.88 & 2.69 & 2.65 \\
\hline Absorption & 0.6 & 1.8 & 0.91 \\
\hline $\begin{array}{l}\text { Bulk } \\
\text { density } \\
\text { (kg/m3) }\end{array}$ & 1769 & 1650 & 1692 \\
\hline
\end{tabular}

Water: water from Khartoum city water distribution system was used in the concrete mix at temperature of $4 \mathrm{C}$ has been cool using ice after conducting chemical analysis of water.

\section{Components of mix materials}

Concrete Mixes Design: the proportions of mixes and amounts of material for all mixture as illustrated table2:

Table 2 Shows the amount and mix proportions

\begin{tabular}{|l|l|l|l|l|l|}
\hline MIXES NO & Mix proportion & Cement $\left(\mathrm{Kg} / \mathrm{m}^{3}\right)$ & Fine Aggregate $\left(\mathrm{Kg} / \mathrm{m}^{3}\right)$ & Course Aggregate $\left(\mathrm{Kg} / \mathrm{m}^{3}\right)$ & W/C Ratio \\
\hline Basalt Mix1 & $1: 1.66: 2.73$ & 410 & 680 & 1120 & 0.5 \\
\hline Basalt Mix 2 & $1: 1.42: 2.44$ & 430 & 610 & 1050 & 0.43 \\
\hline Basalt Mix3 & $1: 1.22: 2.33$ & 450 & 550 & 1050 & 0.46 \\
\hline Granite Mix1 & $1: 1.66: 2.73$ & 410 & 680 & 1120 & 0.5 \\
\hline Granite Mix2 & $1: 1.42: 2.44$ & 430 & 610 & 1050 & 0.43 \\
\hline GraniteMix3 & $1: 1.22: 2.33$ & 450 & 550 & 1050 & 0.46 \\
\hline
\end{tabular}

\section{RESULTS of EXPERIMENTS of FRESH and HARDENED CONCRETE}

The results of fresh and hardened concrete tests for different mix proportions using crashed Basalt and uncrushed Granite as coarse aggregate represented in Table 3 to 11 and depicted graphically in Figures 1 to 7. 
Table 3 Results of slump and Compressive Strength Tests of the Basalt Mix 1

\begin{tabular}{|c|c|c|c|c|c|}
\hline Age & $\operatorname{Area}\left(\mathrm{mm}^{2}\right)$ & Slump(mm) & Failure load(kN) & Compressive strength $\left(\mathrm{N} / \mathrm{mm}^{2}\right)$ & Average Compressive strength $\left(\mathrm{N} / \mathrm{mm}^{2}\right)$ \\
\hline \multirow[t]{3}{*}{ 7days } & \multirow[t]{9}{*}{10000} & \multirow[t]{9}{*}{100} & 485 & 48.5 & \multirow[t]{3}{*}{48.0} \\
\hline & & & 460 & 46.0 & \\
\hline & & & 490 & 49.0 & \\
\hline \multirow[t]{3}{*}{ 28days } & & & 570 & 57.0 & \multirow[t]{3}{*}{55.0} \\
\hline & & & 530 & 53.0 & \\
\hline & & & 550 & 55.0 & \\
\hline \multirow[t]{3}{*}{ 56days } & & & 630 & 63.0 & \multirow[t]{3}{*}{58.0} \\
\hline & & & 580 & 58.0 & \\
\hline & & & 530 & 53.0 & \\
\hline
\end{tabular}

Table 4 Results of Slump and Compressive Strength Tests of the Basalt Mix2

\begin{tabular}{|c|c|c|c|c|c|}
\hline Age & $\operatorname{Area}\left(\mathrm{mm}^{2}\right)$ & Slump(mm) & $\begin{array}{l}\text { Failure } \\
\text { load(kN) }\end{array}$ & $\begin{array}{l}\text { Compressive } \\
\text { strength }\left(\mathrm{N} / \mathrm{mm}^{2}\right)\end{array}$ & $\begin{array}{l}\text { Average Compressive } \\
\text { strength }\left(\mathrm{N} / \mathrm{mm}^{2}\right)\end{array}$ \\
\hline \multirow[t]{3}{*}{7 days } & \multirow[t]{9}{*}{10000} & \multirow[t]{9}{*}{80} & 390 & 39.0 & \multirow[t]{3}{*}{43.0} \\
\hline & & & 450 & 45.0 & \\
\hline & & & 460 & 46.0 & \\
\hline \multirow[t]{3}{*}{28 days } & & & 490 & 49.0 & \multirow[t]{3}{*}{52.0} \\
\hline & & & 580 & 58.0 & \\
\hline & & & 490 & 49.0 & \\
\hline \multirow[t]{3}{*}{ 56days } & & & 550 & 55.0 & \multirow[t]{3}{*}{60.5} \\
\hline & & & 630 & 63.0 & \\
\hline & & & 640 & 640 & \\
\hline
\end{tabular}

Table 5 Results of Slump and Compressive Strength Tests of the Basalt Mix3

\begin{tabular}{|c|c|c|c|c|c|}
\hline Age & $\operatorname{Area}\left(\mathrm{mm}^{2}\right)$ & Slump(mm) & $\begin{array}{l}\text { Failure } \\
\text { load }(\mathrm{kN})\end{array}$ & $\begin{array}{l}\text { Compressive } \\
\text { strength }\left(\mathrm{N} / \mathrm{mm}^{2}\right)\end{array}$ & $\begin{array}{l}\text { Average Compressive } \\
\text { strength }\left(\mathrm{N} / \mathrm{mm}^{2}\right)\end{array}$ \\
\hline \multirow[t]{3}{*}{ 7days } & \multirow[t]{9}{*}{10000} & \multirow[t]{9}{*}{70} & 400 & 40.0 & \multirow{3}{*}{41.5} \\
\hline & & & 460 & 46.0 & \\
\hline & & & 380 & 38.5 & \\
\hline \multirow[t]{3}{*}{ 28days } & & & 520 & 52.0 & \multirow[t]{3}{*}{52.0} \\
\hline & & & 520 & 52.0 & \\
\hline & & & 510 & 51.0 & \\
\hline \multirow[t]{3}{*}{ 56days } & & & 570 & 57.0 & \multirow[t]{3}{*}{57.0} \\
\hline & & & 570 & 57.0 & \\
\hline & & & 480 & 48.0 & \\
\hline
\end{tabular}

Table 6 Results of Slump and Compressive Strength Tests of the Granite Mix1

\begin{tabular}{|c|c|c|c|c|c|}
\hline Age & $\operatorname{Area}\left(\mathrm{mm}^{2}\right)$ & Slump $(\mathrm{mm})$ & $\begin{array}{l}\text { Failure } \\
\text { load }(\mathrm{kN})\end{array}$ & $\begin{array}{l}\text { Compressive } \\
\text { strength }\left(\mathrm{N} / \mathrm{mm}^{2}\right)\end{array}$ & $\begin{array}{l}\text { Average Compressive } \\
\text { strength }\left(\mathrm{N} / \mathrm{mm}^{2}\right)\end{array}$ \\
\hline \multirow[t]{3}{*}{ 7days } & \multirow[t]{9}{*}{10000} & \multirow[t]{9}{*}{80} & 325 & 32.5 & \multirow[t]{3}{*}{40.0} \\
\hline & & & 400 & 40.0 & \\
\hline & & & 395 & 39.5 & \\
\hline \multirow[t]{3}{*}{ 28days } & & & 495 & 49.5 & \multirow[t]{3}{*}{50.5} \\
\hline & & & 510 & 51.0 & \\
\hline & & & 505 & 50.5 & \\
\hline \multirow[t]{3}{*}{ 56days } & & & 575 & 57.5 & \multirow[t]{3}{*}{56.0} \\
\hline & & & 545 & 54.5 & \\
\hline & & & 555 & 55.5 & \\
\hline
\end{tabular}

Table 7 Results of Slump and Compressive Strength Tests of the Granite Mix2

\begin{tabular}{|c|c|c|c|c|c|}
\hline Age & $\operatorname{Area}\left(\mathrm{mm}^{2}\right)$ & Slump(mm) & $\begin{array}{l}\text { Failure } \\
\text { load(kN) }\end{array}$ & $\begin{array}{l}\text { Compressive } \\
\text { strength }\left(\mathrm{N} / \mathrm{mm}^{2}\right)\end{array}$ & $\begin{array}{l}\text { Average Compressive } \\
\text { strength }\left(\mathrm{N} / \mathrm{mm}^{2}\right)\end{array}$ \\
\hline \multirow[t]{3}{*}{ 7days } & \multirow[t]{9}{*}{10000} & \multirow[t]{9}{*}{80} & 480 & 48.0 & \multirow[t]{3}{*}{51.0} \\
\hline & & & 500 & 50.0 & \\
\hline & & & 550 & 55.0 & \\
\hline \multirow[t]{3}{*}{ 28days } & & & 600 & 60.0 & \multirow[t]{3}{*}{53.0} \\
\hline & & & 530 & 53.0 & \\
\hline & & & 460 & 46.0 & \\
\hline \multirow[t]{3}{*}{56 days } & & & 600 & 60.0 & \multirow[t]{3}{*}{60.5} \\
\hline & & & 620 & 62.0 & \\
\hline & & & 590 & 59.0 & \\
\hline
\end{tabular}

Table 8 Results of Slump and Compressive Strength Tests of the Granite Mix3 


\begin{tabular}{|c|c|c|c|c|c|}
\hline Age & $\operatorname{Area}\left(\mathrm{mm}^{2}\right)$ & Slump(mm) & $\begin{array}{l}\text { Failure } \\
\text { load(kN) }\end{array}$ & $\begin{array}{l}\text { Compressive } \\
\text { strength }\left(\mathrm{N} / \mathrm{mm}^{2}\right)\end{array}$ & $\begin{array}{l}\text { Average Compressive } \\
\text { strength }\left(\mathrm{N} / \mathrm{mm}^{2}\right)\end{array}$ \\
\hline \multirow[t]{3}{*}{ 7days } & \multirow[t]{9}{*}{10000} & \multirow[t]{9}{*}{90} & 570 & 57.0 & \multirow[t]{3}{*}{54.0} \\
\hline & & & 530 & 53.0 & \\
\hline & & & 520 & 52.0 & \\
\hline \multirow[t]{3}{*}{ 28days } & & & 580 & 58.0 & \multirow[t]{3}{*}{56.0} \\
\hline & & & 550 & 55.0 & \\
\hline & & & 550 & 55.0 & \\
\hline \multirow[t]{3}{*}{ 56days } & & & 650 & 65.0 & \multirow[t]{3}{*}{64.0} \\
\hline & & & 515 & 51.5 & \\
\hline & & & 625 & 62.5 & \\
\hline
\end{tabular}

Table (9) Average for Results of compressive strength and slump tests (Basalt mixes)

\begin{tabular}{|l|l|l|l|l|}
\hline \multirow{2}{*}{ Basalt mixes } & \multirow{2}{*}{ Slump } & \multicolumn{3}{|l|}{ Average Compressive strength $\mathrm{N} / \mathrm{mm}^{2}$} \\
\cline { 3 - 5 } & & 7 days & 28 days & 56 days \\
\hline Control mix(Basalt) & 0 & 28.5 & 33.0 & 39.0 \\
\hline Basalt mix1 & 100 & 48.0 & 55.0 & 58.0 \\
\hline Basalt mix2 & 80 & 43.0 & 52.0 & 60.5 \\
\hline Basalt mix3 & 70 & 41.5 & 52.0 & 57.0 \\
\hline
\end{tabular}

Table (10) Average for results of compressive strength and slump tests (Granite mixes)

\begin{tabular}{|l|l|l|l|l|}
\hline Basalt mixes & \multirow{2}{*}{ Slump } & \multicolumn{4}{|l|}{ Average Compressive strength N/mm } \\
\cline { 3 - 5 } & & 7 days & 28 days & 56 days \\
\hline Control mix(Granite) & 50 & 40.5 & 49.0 & 54.0 \\
\hline Granite mix1 & 80 & 40.0 & 50.5 & 56.0 \\
\hline Granite mix2 & 80 & 51.0 & 53.0 & 60.0 \\
\hline Granite mix3 & 90 & 54.0 & 56.0 & 64.0 \\
\hline
\end{tabular}

Table (11) Results of mix3 in Granite and Basalt aggregate compared with control mix

\begin{tabular}{|l|l|l|l|l|}
\hline \multirow{2}{*}{ Type of aggregate } & \multirow{2}{*}{ Slump } & \multicolumn{3}{|c|}{ Average Compressive strength N/mm } \\
\cline { 3 - 5 } & & 7 days & 28 days & 56 days \\
\hline Control mix(Basalt) & 0 & 28.5 & 33.0 & 39.0 \\
\hline Control mix(Granite) & 50 & 40.5 & 49.0 & 54.0 \\
\hline Basalt mix3 & 70 & 43.0 & 52.0 & 57.0 \\
\hline Granite mix3 & 90 & 54.0 & 56.0 & 64.0 \\
\hline
\end{tabular}

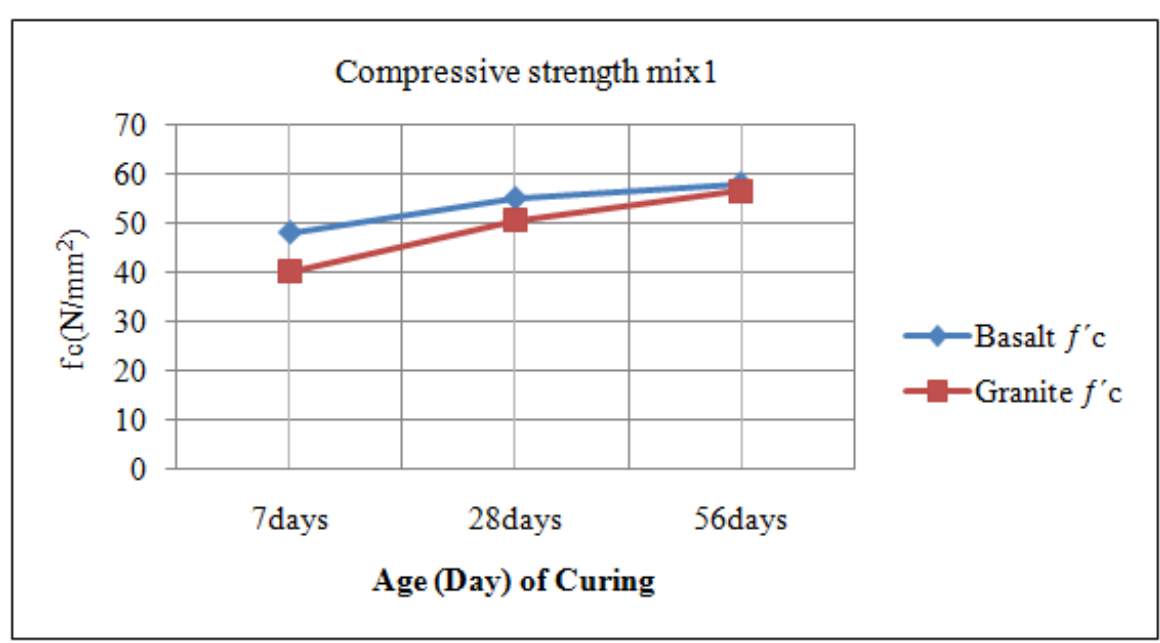

Fig (1) Comparison between strength developments of MIX1 for Basalt \&Granite Aggregate 


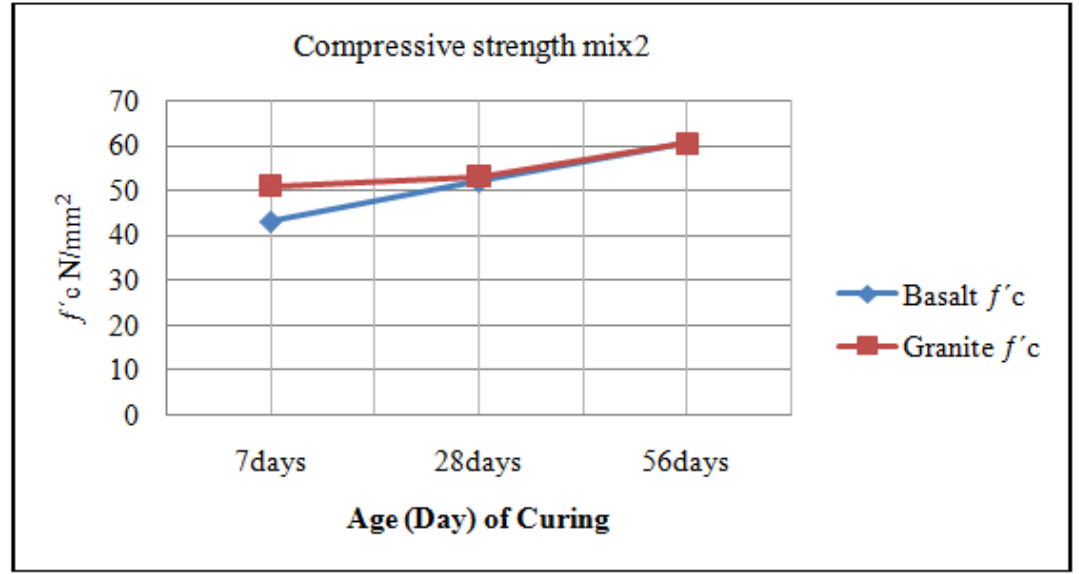

Fig (2) Comparison between strength developments of MIX2for Basalt \&Granite Aggregate

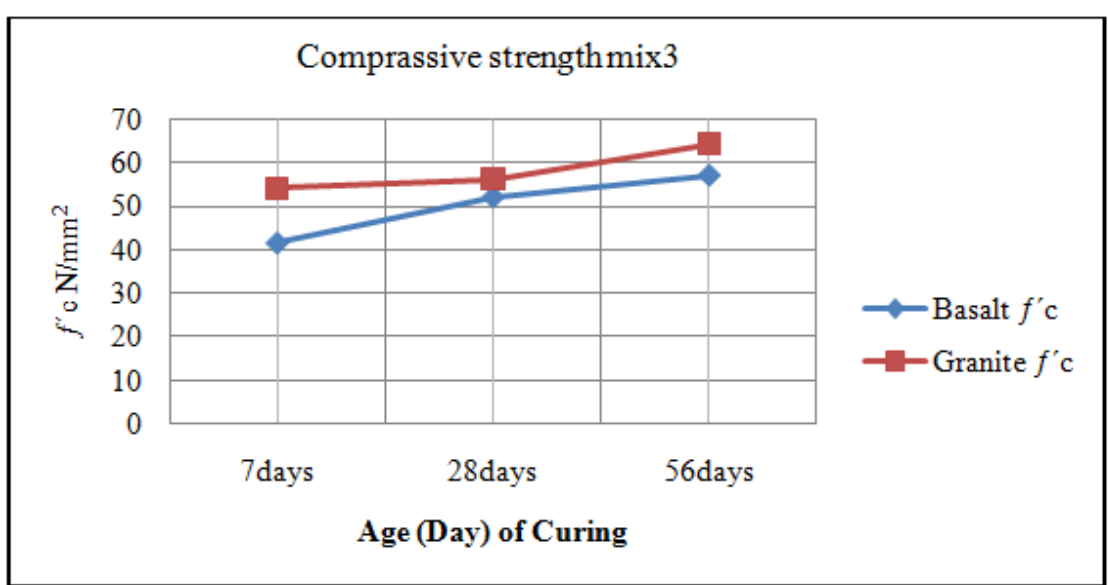

Fig (3) Comparison between strength developments of MIX3for Basalt \&Granite Aggregate

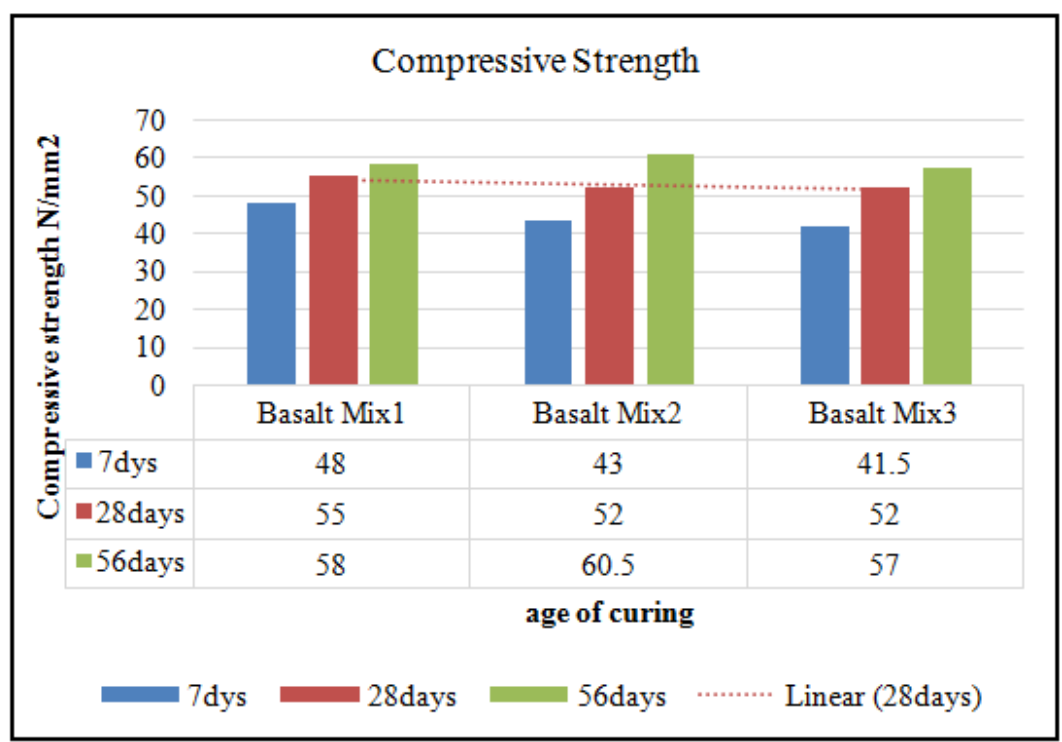

Fig (4) Compressive strength development throughout the ages for crashed Basalt aggregate mixes 


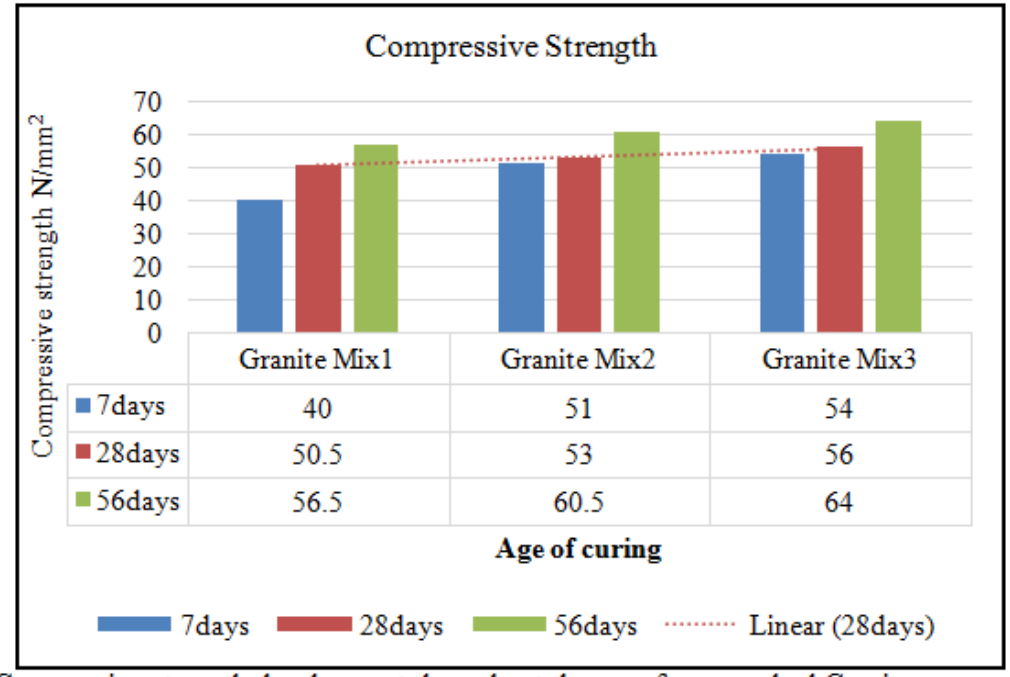

Fig (5) Compressive strength development throughout the ages for uncrushed Granite aggregate mixes

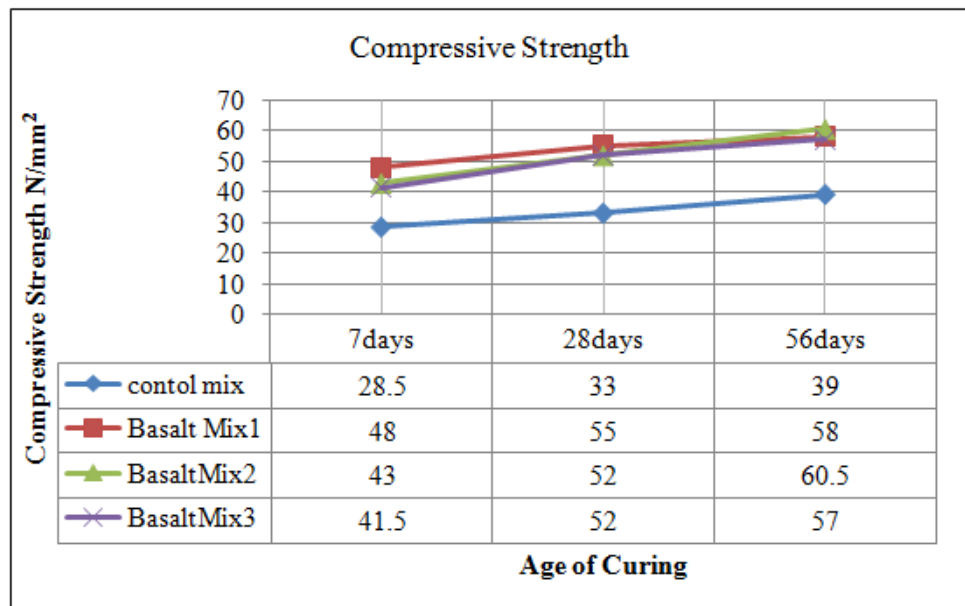

Fig (6) Comparison between strength developments of control mix and Basalt aggregate mixes

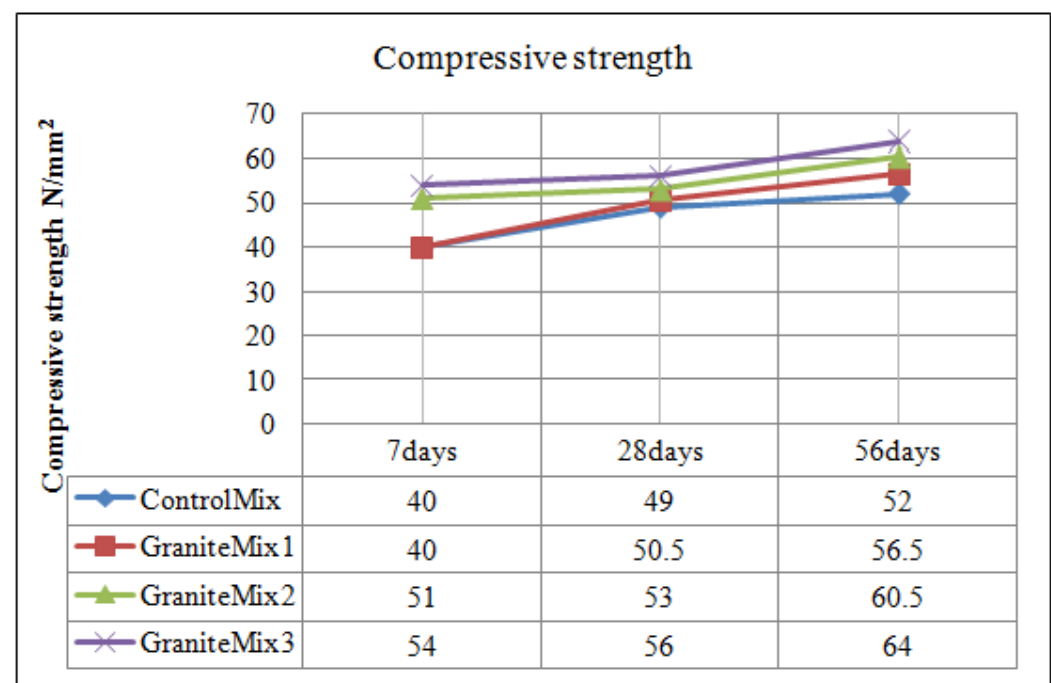

Fig (7) Comparison between strength developments of control mix and Granite aggregate mixes 


\section{DISCUCSSION OF THE RESULTS}

The results obtained from the different mix proportions using high quality crashed basalt and uncrushed granite coarse aggregate are summarized and discussed as following:

1. Table $(3,4,5,10 \& 11)$ shows that the slump values is decreased with in increased of the cement content for basalt aggregate mixes, and its increased within increased of the cement content for granite aggregate mixes but both of them with in range accordance to ACI mix design (25-100) $\mathrm{mm}$.

2. Figure $(1,2 \& 3) \&$ Table $(3,4,5,6,7 \& 8)$ shows that the compressive strength is developed in 7, 28\&56 days for basalt and granite course aggregate.

3. From Fig (4\&6) \& Table (2) the compressive strength is decreased with in increased of the cement content in mix 1 , mix $2 \& \operatorname{mix} 3$ for basalt aggregate mixes.

4. From Fig (5\&7) \& Table (2) Granite mixes it was found that the compressive strength is increased with in increased of the cement content in different mixes of Granite aggregate .also the Figure shows that in Mix3 Granite aggregate mixes in 56days gives the maximum compressive strength than other mixes.

\section{CONCLUSIONS \& RECOMMENDATIONS}

In this study the crashed basalt and uncrushed granite coarse aggregate with high quality for basic material, was used to produce high compressive strength concrete in different ages. From the results obtained it can be concluded that:

1. The significant effects of the high quality uncrushed granite coarse aggregate occurred at mix proportion of (450:1050:550:207) $\mathrm{kg} / \mathrm{m}^{3}$, (cement: coarse aggregate: fine aggregate: water), respectively.

2. The production of $1 \mathrm{~m} 3$ HSC strength of concrete mix proportion (mix3) of material of as follow: cement content $450 \mathrm{~kg} / \mathrm{m}^{3}$, fine aggregate $550 \mathrm{~kg} / \mathrm{m}^{3}$,coarse aggregate $1050 \mathrm{~kg} / \mathrm{m}^{3}$ for Granite aggregate in Water temperature $4^{\circ} \mathrm{C}$ mix temperature $28^{\circ} \mathrm{C}$ and w/c 0.46 .

3. The compressive strength of concrete with in increased of cement content in granite aggregate mixes.

4. The slump values of all mixes, when use high quality crashed basalt and uncrushed granite coarse aggregate with in range accordance to ACI mix design (25-100) $\mathrm{mm}$.

From this study it can be recommended that the uncrushed granite with high material quality, suitable concrete mix proportion and extra quality control procedures can be used to produce high compressive strength concrete.

\section{REFRENCES}

[1] ACI Committee 363 (1984): State-of-the-Art Report on High Strength Concrete, ACI Journal, 81(4), pp.364-411

[2] A.E Florato, PCA Research an "high strength concrete, international" vol.11, No.4,1989 PP.44-50

[3] Allen A. J., et al. (2004), "In-situ quasi-elastic scattering characterization of particle size effects on thehydration of tricacium silicate,"J. Mater. Res., 19, 3242-3254.

[4] Allen, A. J., Thomas, J.J., and Jennings, H.M. (2007) "Composition and density of nanoscalecalcium-silicate-hydrate in cement," Nat. Mater., 6, 311-316

[5] Neville, A.M. (1995) Properties of Concrete 4th Edition, England. Longman ltd. 108-176

[6] A.M Neville "properties of concrete" fourth and final edition, Longman scientific and technical, U.K, 2002

[7] Bang SengChoo, John Newman "Advanced concrete technology." first published, Elesevier. LTd, 2003

[8] Jonbi1,a, BinsarHariandja 1,b ,Iswandi Imran1,c, Ivindra Pane1,d "Development of Mix Proportion For High-Performance Concrete Using Locally Available Ingredients Based on Compressive Strength and Durability"2012 Applied Mechanics and Materials Vols. 174-177 (2012) pp 1067-1071

[9] M. Yaqub, \& Imran Bukhari, 2006 "Effect of Size of Coarse Aggregate on Compressive Strength of High Strength Concrete" CIPREMIER PTE LTD. 